\title{
Distribution of heavy metals in plant communities of the West Siberian Arctic and Subarctic
}

\author{
Elena Popova ${ }^{1, *}$ \\ ${ }^{1}$ Tobolsk complex scientific station UrB RAS, 16, Osipova, St., 626150, Tyumen region, Tobolsk, \\ Russia
}

\begin{abstract}
The paper presents the results of comprehensive studies on the problem of formation of a deposit of heavy metals in plant communities of the West Siberian Arctic and Subarctic. The regularities of the concentration and redistribution of heavy metals in the soil-plant system have been revealed. Excessive accumulation of heavy metals by different plant species is limited by the selectivity of root absorption in relation to certain elements, and therefore it is important to calculate the coefficient of biological absorption. The interrelation between the intensity of recreational loading and change in the nature, grass cover structure.Among the identified pollutants that accumulate by plants identified a group of heavy metals and microelements $(\mathrm{Pb}, \mathrm{Sr}, \mathrm{Cu}, \mathrm{Zn}, \mathrm{Ni})$. It is shown that the linear dependence of the accumulation of metals in the system "soil-plant" is observed only in the range of low concentrations of pollutants in the ground growing. With high concentrations the reverse dependence occurs. Formulated, justified and tested methodical approaches to preparation of complex long-time observations of the natural ecosystems.
\end{abstract}

\section{Introduction}

The anthropogenic impact on the environment can be local (from a single factor) or complex (from a group of different factors). These impacts, as a rule, are characterized by different environmental hazard coefficients depending on the type of impact and its nature, as well as the object of impact.

The phytotoxic effect of heavy metals is manifested, as a rule, at a high level of technogenic pollution of soils and largely depends on the properties and behavioristic features of a particular metal $[1,2,3]$.

To understand the processes of migration and accumulation of heavy metals, it is important to take into account and distinguish the source of their entry into the environment. In the most general terms, natural and man-made sources of heavy metals are distinguished $[4,5,6]$.

One of the scientific methods allowing objective study of biological objects (including plants), along with bioindication methods of assessment, is quantitative chemical analysis.

\footnotetext{
*Corresponding author: Popova-3456@mail.ru
} 
Heavy metals are one of the specific pollutants of roadside ecosystems $[7,8]$. Heavy metals are one of the most common land pollutants. Contamination is assessed on the basis of comparing data on their gross content. Among other technogenic pollutants, heavy metals are distinguished by their ability to accumulate, without physicochemical or biological degradation, in the surface layer of soils and change soil properties, to remain available for root absorption by plants for a long time, and to be actively involved in migration processes along trophic chains. Studying the reaction of plants to pollution of the environment with heavy metals is one of the tasks of biological monitoring of the environment. The specific characteristics of metabolism in various plant species determine their selectivity in accumulation of one or more elements $[9,10,11]$.

Plants can be subdivided into humid-cationic plants (spruce, birch, aspen, mosses, etc.), the centers of origin of which are located in humid regions, and arid-anionic plants (wormwood, feather grass, limonium, sunflower, corn, etc.), which historically originated in arid regions. The formation of humid-cationic plants in humid conditions led to their adaptation to accumulating cationogenic elements ( $\mathrm{Zn}, \mathrm{Mn}, \mathrm{Cu}, \mathrm{Ag}, \mathrm{Pb}, \mathrm{Co}, \mathrm{Sr}, \mathrm{Ni}, \mathrm{Cd}$ ), which have the greatest mobility in these climatic conditions. A characteristic feature of arid-anionic plants is the accumulation of anionogenic chemical elements ( $\mathrm{Mo}, \mathrm{B}, \mathrm{Cr}$, $\mathrm{V}$, Ti, partly $\mathrm{Zr}$ ), as well as some cationogenic elements $(\mathrm{Cu}, \mathrm{Ag}, \mathrm{Pb}, \mathrm{Co}, \mathrm{Sr}, \mathrm{Ni}, \mathrm{Cd})$, the mobility and availability of which for plants under these conditions is due to the formation of soluble complexes with carbonates and bicarbonates $[12,13]$.

The sources of heavy metals entering the soil and the environment are different; in our studies, these are roads [14]. The purpose of this study is to determine the concentration and characteristics of the accumulation of some heavy metals in the ecosystems of the West Siberian Arctic and Subarctic.

\section{Material and methods}

The selection of geobotanical sites and the description of vegetation were carried out according to the methodological techniques adopted in phytocenology and widely used in geobotanical studies. The main method used in the field part of the research was the method for describing communities of terrestrial vegetation. At the geobotanical sites, the species composition of vascular plants at the time of survey and description was identified.

Dimensions and configuration of the area: $10 \mathrm{~m} \times 10 \mathrm{~m}=20 \mathrm{~m}^{2}$. In total, 6 geobotanical descriptions were drawn up during the field studies $[15,16,17]$.

We prepared samples using a microwave digestion system speedwave MWS-2 by PerkinElmer (USA). A weighed portion of soil $(\mathrm{m}=4 \mathrm{~g})$ was placed into a plastic tube to add $\mathrm{HNO}_{3}$ and $\mathrm{HCl}$ at the ratio of $1: 3$. The tube was then placed into the microwave for digestion using the program recommended by the microwave manufacturer and the following heating cycle: temperature increase to $200^{\circ} \mathrm{C}$ in 5 minutes, standing at $200^{\circ} \mathrm{C}$ for 5 minutes, cooling to $45^{\circ} \mathrm{C}$. The sample was transferred to a $15 \mathrm{ml}$ test tube bringing the solution to the volume of $10 \mathrm{ml}$ with deionized water. Afterwards we conducted the analysis.

For plant sample digestion and analysis we selected the most common species of plants at each site. A weighed portion ( $\mathrm{m}=0.3 \mathrm{~g}$ ) was placed into a tube to add $\mathrm{H}_{2} \mathrm{SO}_{4}$ and $\mathrm{H}_{2} \mathrm{O}_{2}$ at the ratio of 1:3. The next digestion steps followed the same order as outlined above.

Quantitative chemical analysis of trace and heavy metals accumulated in soil samples and in the whole phytomass was performed using the inductively coupled plasma method with the atomic emission spectrometer OPTIMA 7000 DV by PerkinElmer (USA). For calibration we used standard solutions by PerkinElmer (USA).

Before measuring the samples, the required parameters for the measurement were set (the background was measured, the necessary calibration was performed (the minimum and 
maximum concentration of $0.05-10 \mathrm{mg} / \mathrm{dm} 3$ ).

Statistical processing of experimental data was performed using the Statistica 10.0 software. The arithmetic mean values (X), the standard errors of the arithmetic mean (SD), and the significance of differences in the arithmetic mean by Student's t criterion were calculated.

Taking into account that processes in the soil-plant system are exposed to many factors and that its behavior needs to be monitored in time to enable prediction of dynamics, it is reasonable to use simulation techniques. To quantify the total ability of species to concentrate microelements, a special indicator of species biogeochemical activity (BCA) is calculated, which is the total value obtained by adding the coefficients of biological absorption of individual microelements: $\mathrm{BCA}=\Sigma \mathrm{Ax}[18]$.

Soils of the observance sites belong to one type and, therefore, meet the uniformity conditions of the selected plots.

In contrast to sod-podzolic soils, these soils have the second humus horizon in their profile.

The upper part of the profile contains a surface horizon (forest floor). AY - humusaccumulative (gray-humus) horizon. EL - eluvial horizon. There are traces of movable iron in the form of rusty and ocherous spots, due to iron-containing films on the surface of mineral grains and aggregates. Transition to BT is abrupt (in terms of color). It contains an ancient humus horizon. EL [hh $\mid$ - the second humus (ancient) horizon in the form of humous lenses, spots, discontinuous horizon. EL. It differs from the recent gray humus horizon in terms of structure and color. BEL - subeluvial transitional horizon represented by a combination of light and dark fragments of overlying and underlying horizons. BT textural horizon, the densest one in the profile, reddish brown. $\mathrm{C}$ - heavy loam source rock, gley, reddish. The structure is not clearly defined. It is plastic and adhesive, cracked under the influence of hydrochloric acid, which indicates the presence of carbonates.

\section{Results}

As a result of a comprehensive study of the Subarctic and Arctic ecotones within Western Siberia, the following key areas were investigated:

Land plot 1 . About $35 \mathrm{~km}$ north of the town of Noyabrsk. The Pyakupur river, the right bank. N 6330.033', E 74³6.577'. Low-level haugh near the river channel. A pioneer community with low $(60 \%)$ total projective cover. Juncetum caricoso-graminosum community.

Land plot 2. The left bank of the Pyakupur river. Hydrogenic ecotone. N 63⒉932', E $74^{\circ} 36.134^{\prime}$ : Low-level haugh near the river channel. A pioneer community with low $(60 \%)$ total projective cover. Juncetum caricosum community.

Land plot 3. About $10 \mathrm{~km}$ north of the town of Purpe. The Pur river, the right bank. N $64^{\circ} 40.225^{\prime \prime}$, E $77^{\circ} 06.564^{\prime \prime}$. Willow trees on the ridge near the river channel. 3-4 $\mathrm{m}$ h willow trees. The crown density is 0.8 . The total projective cover of the grass layer is $50 \%$. Salicetum varieherboso-graminosum community.

Land plot 4. The left bank of the Pur river. N 6440.210', E $77^{\circ} 06.107^{\prime}$. Low-level haugh near the river channel. Varieherboro-caricoso-graminetum community.

Land plot 5. A railway embankment ecoton - northern taiga $\mathrm{N} \mathrm{65} 31.638^{\prime}$, E $77^{\circ} 49.835^{\prime}$. A railway embankment with a gramineous-subshrub-ruderal community. The total projective cover is $70 \%$. Gramineto-fruticeto-ruderatum.

Land plot 6. Highway - northern taiga. N 6542.189', E $78^{\circ} 01.198^{\prime}$. 1. Highway embankment. Ruderal-fescue community. Rudero-Festucetum (ovinae). 
Land plot 7. The watershed ridge extending about $30 \mathrm{~km}$ from the city of Novy Urengoy to the north. Larch bushy-lichen forest-tundra on sandy loam soil. Laricetum cladonioso-Betuletum (nanae). N 66 $05.131^{\prime}$, E $76^{\circ} 19.897$ '.

Land plot 8. The Gulf of $\mathrm{Ob}$ in the city of Yamburg with a high, steep shore. $67^{\circ} 54.885^{\prime} \mathrm{N}, 74^{\circ} 48.944^{\prime} \mathrm{E}$. Tundra over a cliff. The total projective cover is $90 \%$.

In the soils of the studied land plots that are more susceptible to technogenic impacts, the heavy metals content rate varied within the following range: $\mathrm{Cr}(1.30 \div 6.50)$; $\mathrm{Cd}$ $(1.35 \div 2.45)$; $\mathrm{Cu}(3,11 \div 5.75)$; $\mathrm{Ni}(2.00 \div 5.50) ; \mathrm{Pb}(6.18 \div 16.61) ; \mathrm{Sr}(3.25 \div 11.32) ; \mathrm{Zn}$ $(5.22 \div 15.23) \mathrm{mg} / \mathrm{kg}$. By the impact, ecotoxicants can be arranged in a descending order: $\mathrm{Pb}>\mathrm{Zn}>\mathrm{Sr}>\mathrm{Cr}>\mathrm{Cu}>\mathrm{Ni}>\mathrm{Cd}$. By the contamination rate, the land plots can be arranged in the following order: $3>1>>5>7>2>4>8>6$ (Fig. 1).

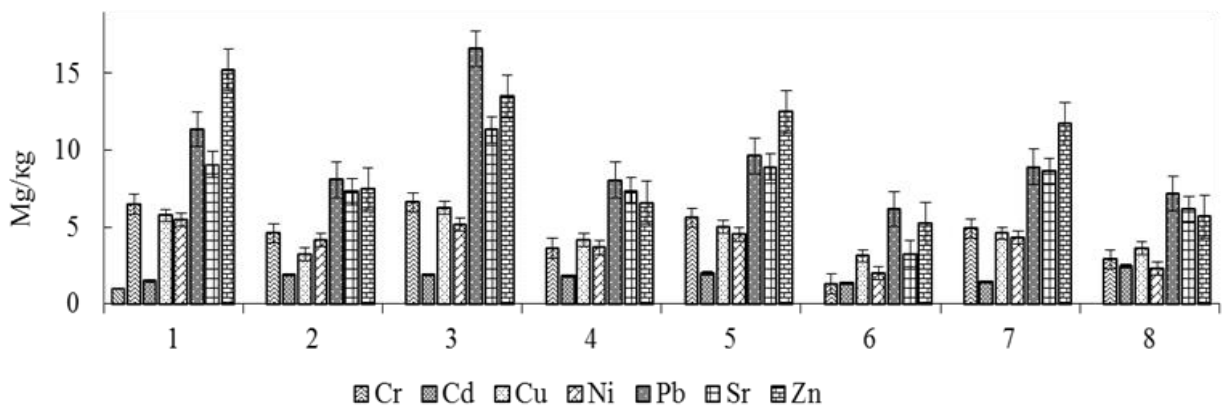

Fig. 1. The content of heavy metals in the soils of the studied land plots.

Heavy metals accumulate not only in the soil, but also in plants. Plants accumulate heavy metals in tissues and on the surface of organs. The highest accumulation of heavy metals in the total biomass was revealed in relation to $\mathrm{Pb}, \mathrm{Sr}, \mathrm{Cu}, \mathrm{Zn}$, and $\mathrm{Ni}$ (Fig. 2).

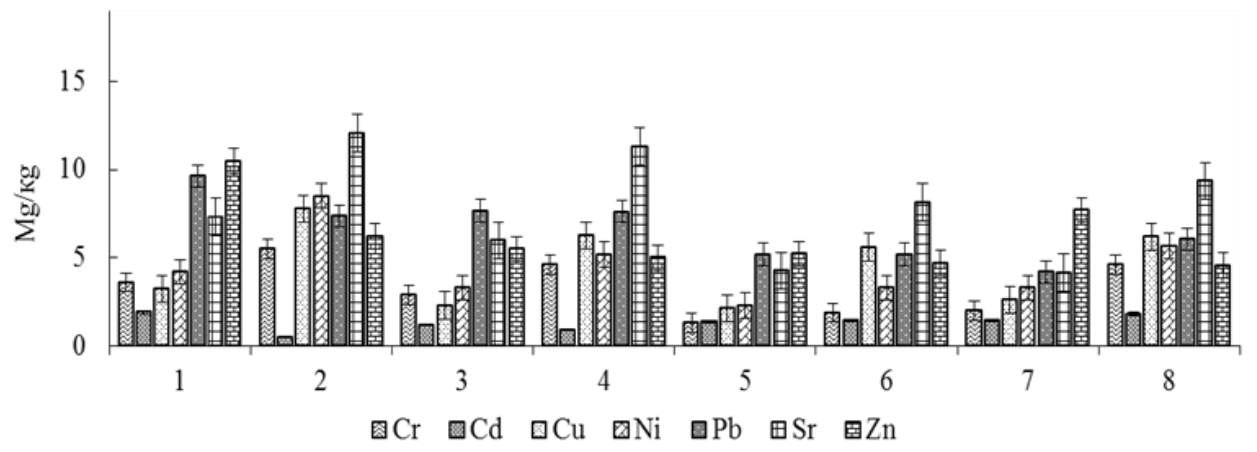

Fig. 2. The content of heavy metals in plants on the studied land plots.

The biological absorption of microelements and heavy metals by plants can be estimated using the coefficient of biological absorption $\mathrm{Ki}_{\mathrm{ba}}$ (see Fig. 3).

Analysis of the results showed differences in the heavy metals accumulation capacity of the studied plants. Excessive accumulation of metals by different plant species is limited by the selective ability of root absorption in relation to certain elements. The highest coefficient of biological absorption was revealed for the following elements: $\mathrm{Ni}(2.03 \div$ $2.44 \mathrm{mg} / \mathrm{kg})$ - land plots No. 2 and 8; Cu $(2.39 \mathrm{mg} / \mathrm{kg})$ - land plot No. 2; $\mathrm{Sr}(2.51 \mathrm{mg} / \mathrm{kg})-$ land plot No. 6 (Fig. 3). 


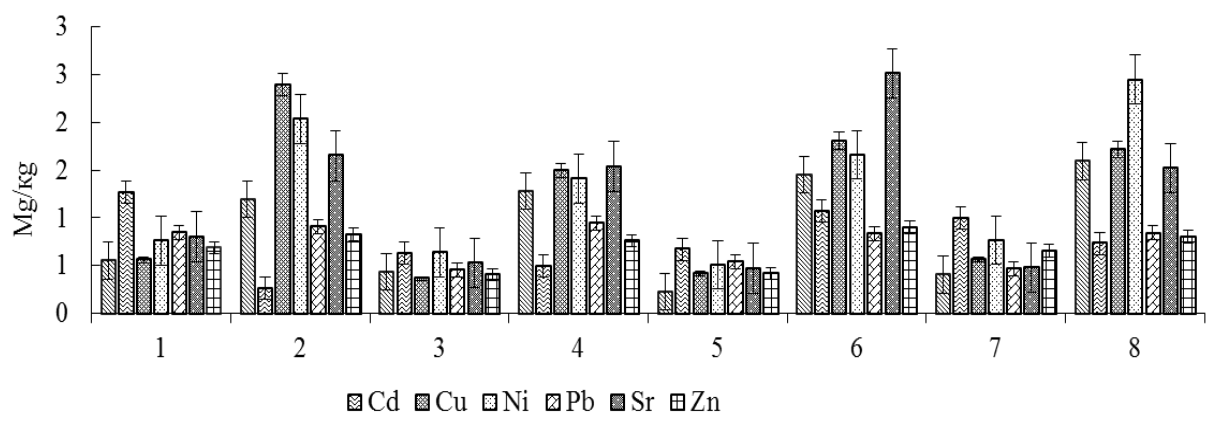

Fig. 3. Coefficient of biological absorption of the studied elements.

The content of $\mathrm{Pb}$ and $\mathrm{Zn}$ in biomass is lower than in soil; such chemical elements belong to the group of biological capture. In this case, both the rate of accumulation of chemical elements and the rate of their capture can be different. The elements, the coefficient of biological absorption of which exceeds 1, are called elements of "biological accumulation" ( $\mathrm{Sr}, \mathrm{Cr}, \mathrm{Cu}, \mathrm{Ni}, \mathrm{Cd}$ ).

An analysis of BCA (biogeochemical activity) showed that by the decrease in biogeochemical activity, the plots can be arranged in the following order: $6(10.24>8$ $(9.65)>2(9.27)>4(7.93)>1(5.49)>7(4.35)>3(3.47)>5(3.27)$.

\section{Discussion}

The main cause of environmental degradation in urban areas is ever increasing anthropogenic pollution of the environment. Among numerous pollutants, heavy metals are considered to be the most toxic ones.

The impact of heavy metals on plants has been studied by researchers from different countries for the past several decades. A significant number of studies, especially ones published in recent years, demonstrate a great and continuing interest in this subject. Among a variety of studies devoted to this subject, there are about two dozen research areas which are under the most active development now. In particular, much attention is paid to the impact of heavy metals on basic physiological processes and productivity of plants, as well as to metal resistance mechanisms of plants acting at different organizational levels.

Citing literature data on the response of plant communities to the impact of anthropogenic pollutants, many researchers have noted that the chemical composition of plants reflects the elemental composition of soils. Therefore, the excessive accumulation of heavy metals by plants is due to their high concentrations in soils. In their life, plants come into contact with only those forms of heavy metals available, the amount of which, in turn, is closely related to the buffering capacity of soils $[19,20]$. Thus, the effect of metals on a plant organism depends on the nature of the element, its content in the environment, the nature of the soil, the form of the chemical compound, and the period from the moment of pollution. The formation of the chemical composition of a plant organism is determined by the biochemical characteristics of various types of organisms, their age and the biochemical laws of the relationship between elements in the organism [21,22]. Plants are good indicators for determining the degree of soil contamination with heavy metal compounds. Despite the significant variability of various plants in terms of accumulation of heavy metals, the bioaccumulation of elements has a definite tendency, allowing them to be divided into several groups (high, medium, and low accumulation). Many authors have noted that lead enters plants mainly through the roots, however, it can be absorbed through the leaves as well. 


\section{Conclusion}

The elemental series of heavy metals in decreasing order based on their concentrations in the soil and the total phytomass of the studied land plots is represented by the following combinations: $\quad \mathrm{Pb}>\mathrm{Zn}>\mathrm{Sr}>\mathrm{Cr}>\mathrm{Cu}>\mathrm{Ni}>\mathrm{Cd} \quad$ (soil); $\mathrm{Sr}>\mathrm{Zn}>\mathrm{Pb}>\mathrm{Ni}>\mathrm{Cu}>\mathrm{Cr}>\mathrm{Cd} \quad$ (total phytomass). For most of the studied metals, there is a tendency for the values of the biological absorption coefficients in plants to decrease as the metals' content in the soil increases, and in the range of low concentrations of chemical elements in the soil, the degree of their absorption by plants increases. The biological absorption coefficients are the main indicators for determining the level of technogenic pollution of the studied phytocenoses and conducting monitoring. Thus, the data obtained to assess the degree of absorption of heavy metals by plants indicate that the studied area is polluted. The difference in the coefficients of biological accumulation makes it possible to classify metals into three categories: high accumulation rates $-\mathrm{Pb}, \mathrm{Sr}, \mathrm{Zn}$; medium $-\mathrm{Cu}, \mathrm{Ni}, \mathrm{Cr}$; low $-\mathrm{Cd}$.

It is shown that the linear relationship of metal accumulation in the soil-plant system is observed only in a low concentration range of pollutants in the growing environment. The inverse relationship is observed at high concentrations: the higher is the content of an element in the environment, the lower is its degree of absorption.

Research in this area contributes to a deeper understanding of the processes of anthropogenic transformation of floristic complexes and should be the basis for environmental monitoring of disturbed habitats.

\section{References}

1. J.M. Arenas, A. Escudero, I. Mola, M.A. Casado, Applied Vegetation Science 20(4), 527-537 (2017)

2. P. Ranta, J. Kesulahti, A. Tanskanen, V. Viljanen, T. Virtanen, Urban Ecosystems 118(2), 341-354 (2014)

3. L. Kullman, Journal of Ecology 86(2), 421-428 (1998)

4. M. Jaźwa, W. Heise, B. Klimek, Factors Bulletin of Environmental Contamination and Toxicology 97(4), 554-560 (2016)

5. D. Jewitt, P.S. Goodman, B.F.N. Erasmus, T.G. O'Connor, T.F. Witkowski, Environmental Management 59(5), 792-806 (2017)

6. F. Aloulou, M. Kallell, H. Belayouni, Environmental Forensics 12(3), 290-299 (2011)

7. T.F. Koyanagi, T. Furukawa, Biological Conservation 167, 1-8 (2013)

8. L. Kütt, T. Paal, K. Lõhmus, I. Rammi, Kr. Zobel, J. Liira, Applied Vegetation Science 21(3), 363-372 (2018)

9. M. Veličković, T. Savić, Plant Biosystems - An International Journal Dealing with all Aspects of Plant Biology 144(3), 692-702 (2010)

10. W. Bertoldi, A. Gurnell, River Res Applic 36(7), 1183-1201 (2020)

11. J.R. Milligan, R.A. Krebs, K.M. Tarun, International Journal of Plant Sciences 169(5), 625-630 (2008)

12. K. Staab, F.A. Yannelli, M. Lang and J. Kollmann, Ecological Engineering 84, 104$112(2015)$

13. P.M. Tikka, P.S. Koski, R.A. Kivelä, M.T. Kuitunen, Applied Vegetation Science 3, 25-32 (2000)

14. C. Freeman, J.H. Graham, M. Tracy, J.M. Emlen, and C.L. Alados, International Journal of Plant Sciences 160, 157-166 (1999) 
15. P.V. Kulikov, Identifier of vascular plants of the Chelyabinsk region (UrB RAS Ekaterinburg, 2010)

16. S.K. Cherepanov, Vascular plants of the USSR (Science, Leningrad, 1981)

17. S. Gustafson, D. Wang, Journal of Environmental Quality 31(1), 350-357 (2002)

18. N.I. Naumenko, Flora and vegetation of the southern Zuraliy (Kurgan University, Kurgan, 2004)

19. L.V. Shumilova, Botanical geography of Siberia (Publishing house of Tomsk University, Tomsk, 1962)

20. H. Krause, K. Culmsee, C. Wesche Leuschner, Folia Geobotanica 50(3), 253-266 (2015)

21. R, Fekete, V. Löki, R. Urgyán et al., Ecology and Evolution 9(11), 6655-6664 (2019)

22. A. Bykov, Ecological dictionary (Science, Alma-Ata, 1983)

23. L.V. Shumilova, Botanical geography of Siberia (Publishing house of Tomsk University, Tomsk, 1962) 